\title{
나노낱알 $\mathrm{SnO}_{2}-\mathrm{ZnO}$ 복합전극의 제조 및 염료감응 태양전지 특성연구 \\ 이정훈 · 문수연 · 신유주* \\ 가톨릭대학교 화학과
}

(접수 2011. 12. 7; 게재확정 2011. 12. 20)

\section{Fabrication of Nano-Grain $\mathrm{SnO}_{2}-\mathrm{ZnO}$ Composite Electrodes and Their Photovoltaic Properties for Dye-Sensitized Solar Sell}

\author{
Jung-Hoon Lee, Soo-Yeon Moon, and Yu-Ju Shin* \\ Department of Chemistry, the Catholic University of Korea, Bucheon, Gyeonggi-do 422-743, Korea \\ ${ }^{*}$ E-mail: yujushin@catholic.ac.kr
}

(Received December 7, 2011; Accepted December 20, 2011)

주제어: 나노낱알 구조, $\mathrm{SnO}_{2}-\mathrm{ZnO}$ 전극, 광전특성 염료감응 태양전지

Key words: Nano-grain structure, $\mathrm{SnO}_{2}-\mathrm{ZnO}$ electrode, Photovoltaic properties, Dye-Sensitized Solar Sell

\section{서 론}

염료감응 태양전지는(Dye sensitized solar cell; DSSC) 기존 실리콘 태양전지에 비해 낮은 제조원가, 투명성, 유 연성 및 다양한 채색성으로 인해 많은 연구가 수행되고 있다. $\mathrm{TiO}_{2}$ 나노입자는 대표적인 광전극 물질로 이를 적 용한 DSSC는 $11 \%$ 의 높은 에너지 변환 효율을 달성한 바 있다. ${ }^{1,2}$ 최근에는 보다 높은 효율을 달성하기 위해서 나 노볼, ${ }^{3,4}$ 나노막대 5,6 등 다양한 나노구조물을 전극에 적용 하거나, $\mathrm{TiO}_{2}$ 를 대체할 수 있는 다양한 전극물질 개발이 활발하게 진행되고 있다. 광전현상을 나타내는 금속산화 물로는 $\mathrm{TiO}_{2}$ 이외에도 $\mathrm{ZnO}, \mathrm{SnO}_{2}, \mathrm{Nb}_{2} \mathrm{O}_{5}, \mathrm{WO}_{3}$ 등이 알려 져 있으나, ${ }^{7-10}$ 이들 중 $\mathrm{ZnO}$ 와 $\mathrm{SnO}_{2}$ 가 가장 집중적으로 연 구되고 있다.

$\mathrm{ZnO}$ 는 (밴드갭 $3.2 \mathrm{eV}$ ) 전도띠 에지 에너지가 $\mathrm{TiO}_{2}$ 와 거의 비슷하다는 점과 ${ }^{11}$ 다양한 나노구조물이 가능하다 는 점에서 전극물질로 강점이 있으나, 염기성이 높아(등 전점 $\mathrm{pH}=9$ ) 유기산인 루테늄 염료에 표면이 용해되는 단 점으로 응용에 한계를 보이면서 최대 효율은 5-6\% 정도에 머무르고 있다. ${ }^{12}$ 이와는 반대로 $\mathrm{SnO}_{2}$ (밴드갭 $3.4 \mathrm{eV}$ )는 산에 대한 안정성은 뛰어나지만, 전도띠 에지 에너지 준 위가 $\mathrm{TiO}_{2}, \mathrm{ZnO}$ 에 비해 약 $0.3 \mathrm{~V}$ 낮아 기전력(Voc) 이 0.3$0.4 \mathrm{~V}$ 로 비교적 작고효율 역시 $1-2 \%$ 로 낮다는 단점이 있 다. ${ }^{13,14}$ 이는 $\mathrm{SnO}_{2}$ 의 나노입자의 크기가 $4-5 \mathrm{~nm}$ 정도로 매우 작 아 표면 상태(surface trap state)의 농도가 높고 recombination 이 빠르게 일어난다는 점과 전극막 내부에 형성되는 공
극의 크기가 작아 적절한 전해질 확산경로를 확보하기가 어렵기 때문이다. ${ }^{15}$ 그러나 나노볼 형태 등 2 차 나노구조 를 도입하거나, ${ }^{16} \mathrm{SnO}_{2}$ 전극 표면을 $\mathrm{MgO}$ 등으로 코팅처 리하면, $\mathrm{Voc}$ 가 크게 증가하고 이에 따라 효율 역시 증가 하는 연구도 보고된 바 있다. ${ }^{17,18}$

특히 $\mathrm{ZnO}$ 와 $\mathrm{SnO}_{2}$ 를 아세트산의 존재 하에 혼합한 복합 전극 $\mathrm{DSSC}$ 의 경우, 효율이 3-5.1\%로 향상되는데 이는 광 전자의 전극 내 주입과정과 확산과정이 개선되었기 때문 으로 보고된 바 있다. ${ }^{19}$ 그러나 아세트산이 $\mathrm{ZnO}$ 를 용해시 킨다는 것을 고려하면 이러한 $\mathrm{ZnO}-\mathrm{SnO}_{2}$ 복합전극은 $\mathrm{ZnO}$ $@ \mathrm{SnO}_{2}$ core-shell 입자전극의 성격이 크고, 전술한 바 와 같이 표면상태의 개선에 의한 것이라는 해석도 가능하다. 본 논문에서는 이러한 용해된 $\mathrm{ZnO}$ 성분이 없는 단순 나 노볼 $\mathrm{SnO}_{2}-\mathrm{ZnO}$ 복합전극을 아세트산 없이 제작하고 이 를 적용한 $\mathrm{DSSC}$ 의 광전특성을 조사하여 $\mathrm{SnO}_{2}-\mathrm{ZnO}$ 복합 화의 영향에 대하여 연구를 수행하였다.

\section{실 험}

$\mathrm{SnO}_{2}$ 수용액 콜로이드와 (Alfa Aesar; $4-5 \mathrm{~nm}, 15 \%$ 수용 액) $200 \mathrm{~nm}$ 크기의 $\mathrm{ZnO}$ 를 혼합하여 복합전극재료로 사용 하였다. $\mathrm{ZnO}$ 는 보고된 바와 같이 물의 함량을 조절하여 sol-gel 법으로 합성하여 사용하였다. ${ }^{16,20,21} 0.15 \mathrm{M} \mathrm{Zn}$ $(\mathrm{CHCOO})_{2} \cdot 2 \mathrm{H}_{2} \mathrm{O}$ 에탄올 용액 $400 \mathrm{~mL}$ 를 20 분간 환류한 후 얼음으로 냉각하였다. 여기에 $0.21 \mathrm{M} \mathrm{LiOH} \cdot \mathrm{H}_{2} \mathrm{O}$ 에탄올 용액 $400 \mathrm{~mL}$ 를 1 시간에 걸쳐 강한 교반과 함께 적가 하였 
다. 이 $\mathrm{Zn}$-acetate-OH 졸 용액에 $56 \mathrm{~mL}$ 의 증류수를 다시 2 시간에 걸쳐 적가하면 약간 탁한 $\mathrm{ZnO}$ sol 용액이 얻어지 는데, 이를 $150{ }^{\circ} \mathrm{C}$ 에서 6 시간 동안 수열반응을 시키면 $200 \mathrm{~nm} \mathrm{ZnO}$ 입자를 얻게 된다. 생성물은 에탄올로 여러 번 세척하여 회수하였다. $\mathrm{SnO}_{2}-\mathrm{ZnO}$ 혼합전극용 페이스 트는 $\mathrm{SnO}_{2}$ 대비 $\mathrm{ZnO}$ 의 질량비 $\mathrm{ZnO} / \mathrm{SnO}_{2}$ 를 $0-100 \%$ 로 변 하시키면서 제조하였다. $40 \mathrm{w} \%$ 의 hydroxypropylcellulose (HPC, Aldrich, M.W.=80,000)가 고분자 thicker로 사용되 었고, 전체 산화물의 질량비가 $13 \mathrm{w} \%$ 가 되도록 에탄올을 첨가한 후 24 시간 강하게 교반하여 점도가 높은 페이스 트를 준비하였다 이 페이스트를 FTO glass에 (Pilkington TEC 8) doctor blade 법으로 도포하였고, 5 시간 동안 상온 에서 건조한 후 $500{ }^{\circ} \mathrm{C}$ 에서 30 분간 소결하여 광전극막을 완성하였다. 이렇게 준비된 전극막들은 $0.3 \mathrm{mM}$ ruthenium dye $\mathrm{Ru}\left[\mathrm{dcbpy}(\mathrm{TBA})_{2}\right]_{2}(\mathrm{NCS})_{2}[\mathrm{~N} 719]$ 에탄올 염료용액에 넣고 $60{ }^{\circ} \mathrm{C}$ 에서 두 시간 동안 방치하여 염료를 흡착시킨 후 에탄올로 세척한 후 상온에서 건조하였다. 광전극 양 극은 나노 Pt 입자가 코팅된 FTO glass를 사용하였고 두 전극판은 열가소성 필름 Surlyn(Dupont; $\mathrm{t}=30-\mu \mathrm{m}$ )를 이용 하여 결합되었다. 산화환원 전해질은 $0.6 \mathrm{M} \mathrm{1-hexyl-2,3-}$ dimethyl imidazolium iodide(C6DMI), 0.2 M LiI, 0.04M I2, 그리고 $0.5 \mathrm{M}$ tert-butyl pyridine(TBP)를 3-methoxy propionitrile (MPN)/acetonitrile(ACN) (1:1v/v)의 혼합용매에 녹여 5시 간 교반한 후 사용하였다.

FE-SEM사진은 Jeol사의 JSM 700F를 이용하여 촬영되
었으며 I-V 거동은 Xenon 램프가 장착된 Yamasida Denso 사의 solar simulator(Class A)를 이용하여 AM 1.5 global 조건하에서 Kiethley 2400 digital source-meter를 이용하여 측정되었다. 표준조사량은 NREL에서 인증한 표준 단결 정 $\mathrm{Si}$-태양전지를 이용하여 보정하였다. IPCE는 Photovoltaic Measurement 사의 Xenon 램프를 광원으로 한 IPCE spectrometer 를 이용하여 400-800nm 영역에서 측정되었고 할로겐 백 색광이 바이아스광으로 적용되었다.

\section{결과 및 논의}

Fig. 1은 $\mathrm{SnO}_{2}-\mathrm{ZnO}$ 복합전극의 FE-SEM 사진이다. $\mathrm{ZnO}$ 가 첨가되지 않은 순수한 $\mathrm{SnO}_{2}$ 전극은 $5 \mathrm{~nm}$ 정도의 미세 $\mathrm{SnO}_{2}$ 입자가 평탄한 표면을 이루고 있고 작은 공극들이 사이에 존재함을 알 수 있다. 반면에 $\mathrm{ZnO}$ 입자가 첨가된 모든 복합전극은 $\mathrm{SnO}_{2}-\mathrm{ZnO}$ 입자들이 서로 agglomeration 되어 $900 \mathrm{~nm}$ 정도 직경의 낱알형의 복합입자가 형성되어 이들이 서로 연결되어 전극이 형성된 것을 보여준다. $\mathrm{ZnO}$ 의 함량이 $20 \%$ 이상으로 증가한 복합전극에서는 $\mathrm{ZnO}$ 입 자가 표면에서 관찰되는데, 이는 복합입자들의 형성 과정 을 시사하고 있다. 즉, $\mathrm{ZnO}$ 입자들은 $\mathrm{SnO}_{2}$ 콜로이드 용액 내로 첨가될 때 매우 잘 분산되고 이 과정에서 미세한 $\mathrm{SnO}_{2}$ 입자들이 $\mathrm{ZnO}$ 표면에 부착되어 $\mathrm{SnO}_{2}-\mathrm{ZnO}$ 복합입자 단위가 만들어지고, 이들이 남아있는 $\mathrm{SnO}_{2}$ 입자와 함께 복합입자를 형성하는 것으로 판단된다. $\mathrm{ZnO}$ 함량이 낮은
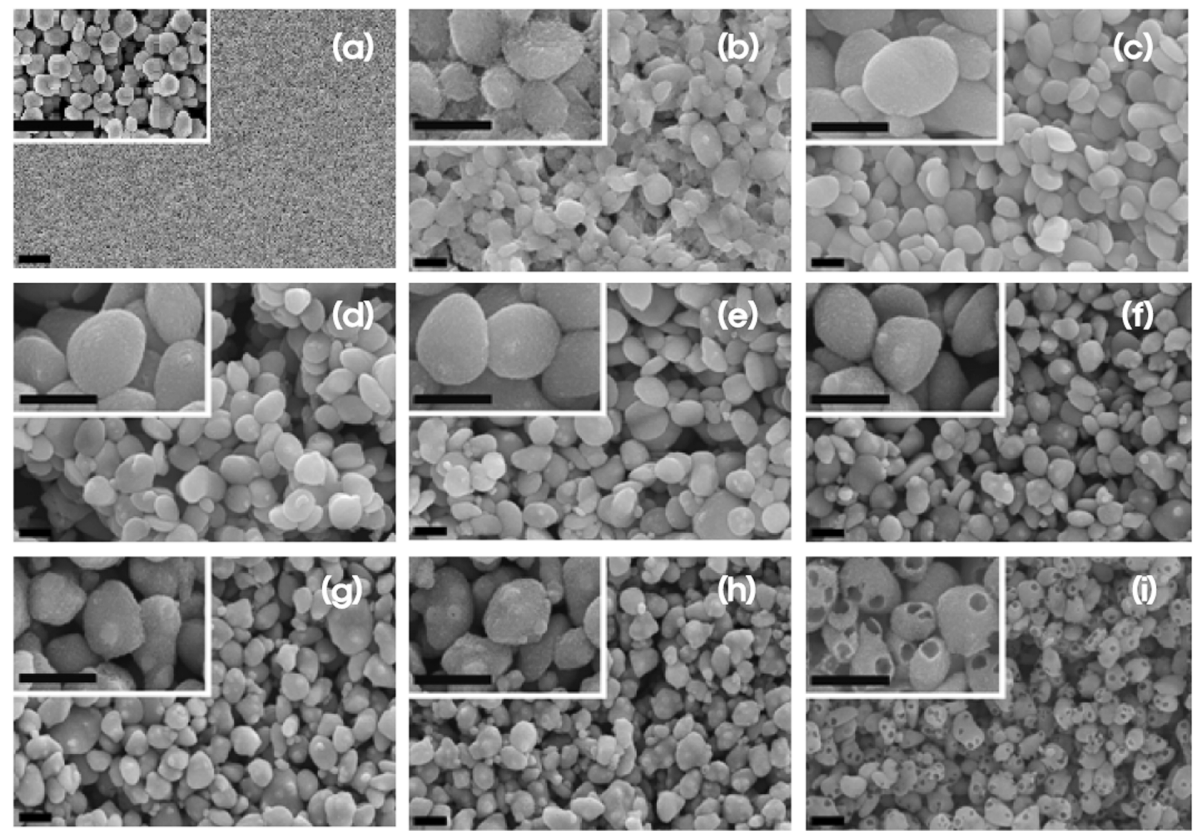

Fig. 1. $\mathrm{SnO}_{2}-\mathrm{ZnO}$ 전극막의 FE-SEM 사진. (a) $\mathrm{SnO}_{2}$ 나노입자 전극 (inset; $200 \mathrm{~nm} \mathrm{ZnO}$ ), (b) $\mathrm{ZnO} / \mathrm{SnO}_{2}=5 \%$, (c) $10 \%$, (d) $20 \%$, (e) $30 \%$, (f) $50 \%$, (g) $70 \%$, (h) $100 \%$, (i) $\mathrm{ZnO} / \mathrm{SnO}_{2}=100 \%$ 를 $5 \mathrm{M}$ 아세트산으로 14 시간 처리한 전극. 스케일 바는 $1 \mu \mathrm{m}$. 

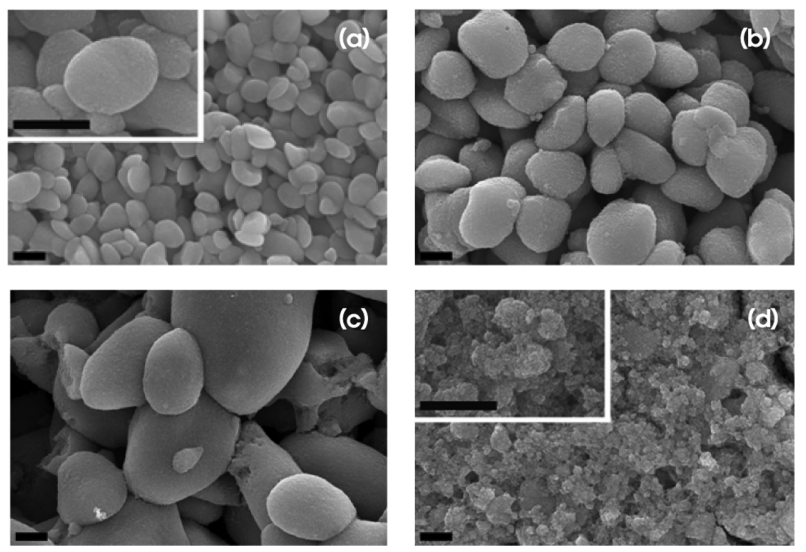

Fig. 2. $\mathrm{SnO}_{2}-\mathrm{ZnO}$ 복합전극 $\left(\mathrm{ZnO} / \mathrm{SnO}_{2} 10 \%\right)$ 의 FE-SEM 사진. 원래 전극 (a), 물 (b), $1 \mathrm{M}$ 암모니아 (c) 및 에탄올을 (d) $10 \mathrm{w} \%$ 첨가한 페이스트로 제작한 전극. 스케일 바는 $1 \mu \mathrm{m}$.

경우 복합입자의 표면에서 $\mathrm{ZnO}$ 를 관찰하기가 어려운 것 도 이러한 논의를 뒷받침하고 있다. $\mathrm{SnO}_{2}$ 입자수가 충분 한 경우 $\mathrm{ZnO}$ 의 표면을 모두 잘 감싸서 $\mathrm{ZnO}$ 가 외부로 노 출되지 않도록 하는 것이 가능하지만 $\mathrm{ZnO}$ 의 함량이 상대 적으로 높아 $\mathrm{SnO}_{2}$ 의 입자수가 줄어들게 되면 $\mathrm{ZnO}$ 의 표면 을 완벽하게 감싸는 것이 불가능해지고 이에 따라 $\mathrm{ZnO}$ 의 표면이 외부에 노출된 채로 복합입자가 형성될 것이기 때문이다. ${ }^{16}$

Fig. 2는 $\mathrm{SnO}_{2}-\mathrm{ZnO}$ 콜로이드 용액( $\left.\mathrm{ZnO} 10 \%\right)$ 에 물, $1 \mathrm{M}$ 암모니아 및 에탄올을 $10 \mathrm{w} \%$ 첨가할 때 나타나는 복합입 자의 변화를 나타낸 것이다. 물을 첨가하면 입자의 크기 는 $2 \mu \mathrm{m}$ 정도로, 암모니아를 첨가한 경우 3-5 $\mu \mathrm{m}$ 크기로 크게 증가하였다. 반면에 에탄올의 경우 복합입자가 잘 형성되지 않았다. 이러한 결과는 $\mathrm{OH}^{-}$이온농도가 $\mathrm{ZnO}$, $\mathrm{SnO}_{2}$ 입자표면 $-\mathrm{OH}$ 기의 농도에 영향을 미칠 것임을 고려 할 때 복합입자가 형성될 때의 입자간 상호작용은 주로 $\mathrm{ZnO}$ 와 $\mathrm{SnO}_{2}$ 의 표면에 존재하는 -OH기를 통한 수소결합 을 통해 이루어진다고 생각된다.

$\mathrm{SnO}_{2}$ 전극처럼 전극표면이 단순한 미세 나노입자의 집 합체로 형성되는 경우와는 달리 본 연구에서 합성된 $\mathrm{SnO}_{2}-\mathrm{ZnO}$ 복합입자는 전극 내에 매우 큰 공극을 형성하 게 된다. 이는 전해질의 침투와 확산에 매우 유리할 것으 로 생각된다. 한편, 일부 복합전극들은 아세트산 $5 \mathrm{M}$ 로 14 시간 처리하여 $\mathrm{ZnO}$ 를 제거하는 것을 시도하였는데, $\mathrm{ICP}$ 분석결과 $\mathrm{ZnO}$ 의 함량이 높을수록 제거되는 비율은 점점 낮아져 $\mathrm{ZnO}$ 의 초기 함유량 대비 제거된 비율 $\mathrm{ZnO}_{\text {제거/ }}$

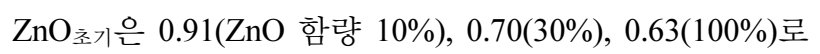
각각 나타났다. 이 결과는 $\mathrm{ZnO}$ 의 함량이 높은 복합입자 의 경우 아세트산 용액이 내부로 침투해가는 것이 점점 어려워진다는 것을 의미하고 이는 $\mathrm{SnO}_{2}-\mathrm{ZnO}$ 복합입자 내
에서 $\mathrm{ZnO}, \mathrm{SnO}_{2}$ 입자간 결합이 더욱 강해져 치밀한 구조 를 형성하는 것을 의미한다. DSSC의 전극특성의 관점에 서 보면 복합전극의 치밀한 구조는 첫째로 염료분자, 전 해질의 복합입자 내 침투가 어려워질 것과, 둘째로는 복 합 입자간 $\mathrm{SnO}_{2}$ 에 의한 연결 상태가 악화될 가능성 또한 시사하고 있다. 또한 Fig. 2(i)에서 나타난 바와 같이 제거 된 $\mathrm{ZnO}$ 가 남기는 표면의 구멍은 그 크기가 $\mathrm{ZnO}$ 와 일치하 여 (Fig. 2(a)) 두 입자의 혼합과정에서 $\mathrm{ZnO}$ 가 용해되지 않았음을 확인할 수 있었다.

Fig. 3은 $\mathrm{SnO}_{2}-\mathrm{ZnO}$ 복합전극 $\mathrm{DSSC}$ 의 I-V 특성 거동을 보여주고 있다. $\mathrm{SnO}_{2}$ 단순 전극의 $\mathrm{I}-\mathrm{V}$ 특성은 $\mathrm{Voc}=0.465 \mathrm{~V}$, $\mathrm{Jsc}=7.49 \mathrm{~mA} / \mathrm{cm}^{2}, \mathrm{ff}=47.7 \%$, 에너지변환효율 $=1.66 \%$ 로 기 존 연구결과와 비슷하게 나타났다. $\mathrm{ZnO}$ 가 첨가되면 초기 에 $\mathrm{Voc}$ 는 급격하게 증가하고 $30 \%$ 이후에는 $0.71 \mathrm{~V}$ 근방에 서 안정화 되었다. $\mathrm{ff}$ 역시 $\mathrm{Voc}$ 와 유사하게 $\mathrm{ZnO}$ 의 첨가에 따라 70-75\% 영역으로 크게 증가하였다. 반면에 $\mathrm{Jsc}$ 는 $\mathrm{ZnO} 5 \%$ 까지만 약간 증가하다가 이후에는 감소하여 $\mathrm{ZnO}$ $50 \%$ 의 경우 $1.82 \mathrm{~mA} / \mathrm{cm}^{2}$ 의 최소값을 보여주는데 이는 초 기값 대비 $1 / 4$ 에 해당한다. 이후 다시 증가하여 $\mathrm{ZnO}$
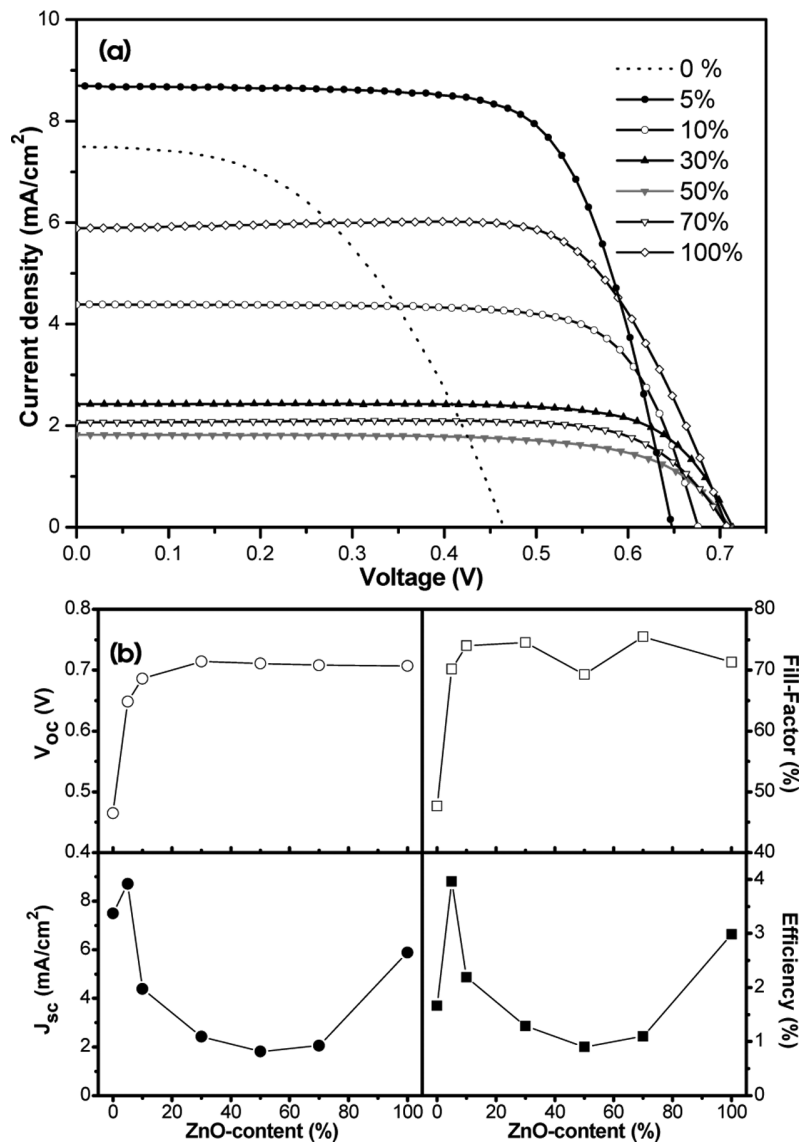

Fig. 3. 나노낱알 $\mathrm{SnO}_{2}-\mathrm{ZnO}-\mathrm{DSSC}$ 의 I-V 커브와 (a) 주요 광전 상수의 변화추이 (b). 
$100 \%$ 는 $5.88 \mathrm{~mA} / \mathrm{cm}^{2}$ 을 나타내었다. 변환효율의 전체적 인 거동은 $\mathrm{Jsc}$ 와 유사하였다. 즉 $\mathrm{ZnO} 5 \%$ 의 경우 $3.96 \%$ 로 최대효율을 보였고, 다시 2.19\%(10\%), 1.29\%(30\%), 0.90\% $(50 \%)$ 로 감소하다가 $1.10 \%(70 \%), 2.98 \%(100 \%)$ 로 증가하는 거동을 나타내었다.

$\mathrm{SnO}_{2}$ 는 $\mathrm{TiO}_{2}$ 에 비해 $\mathrm{CBE}$ 가 약 $0.3 \mathrm{eV}$ 가 더 낮은 에너지 준위를 나타내고 있어 $\mathrm{Voc}$ 의 감소는 불가피하다. 또한 $\mathrm{SnO}_{2}$ 입자는 높은 표면상태(surface trap state)를 나타내고 $\mathrm{SnO}_{2} \rightarrow \mathrm{I}^{-} / \mathrm{I}_{3}^{-}$전해질로의 빠른 전하재조합(recomibation) 으로 Voc는 더 낮아지는 것으로 알려져 있다. 본 연구에 서 관측된 나노입자 전극의 $0.465 \mathrm{~V}$ 는 이를 반영하고 있 다. $\mathrm{SnO}_{2}-\mathrm{ZnO}$ 의 복합전극은 많은 연구자에 의해 조사되 었고 괄목할 만한 변환효율의 증대가 보고되었다. 그 원 인으로는 크게 두 가지 요인이 고려되고 있는데, 첫째로 는 $\mathrm{ZnO}$ 가 $\mathrm{SnO}_{2}$ 표면에 코팅되어 퍼텐셜에너지 장벽의 역 할을 하는 것이다. $\mathrm{ZnO}$ 의 $\mathrm{CBE}$ 는 $\mathrm{TiO}_{2}$ 와 유사한 위치에 존재하므로, $\mathrm{SnO}_{2}$ 입자 표면의 낮은 에너지를 갖는 전자 들이 $\mathrm{I}^{-} / \mathrm{I}_{3}^{-}$전해질로 이동하는 것을 제한하는 것이다. 이러 한 core-shell 형태의 복합전극들은 $\mathrm{Zn}$-acetate 등을 $\mathrm{SnO}_{2}$ 콜로이드에 첨가하여 제조되어 $\mathrm{Voc}$ 및 변환효율의 향상 을 보여준다. ${ }^{22}$ 다른 방법으로는 크기가 큰 $\mathrm{ZnO}$ 입자를 $\mathrm{SnO}_{2}$ 와 섞어 복합전극을 만드는 것으로 이때에는 높은 운동에너지를 갖는 전자들로 인한 전하분리가 크게 개선 되는 것으로 제안된 바 있고 변환효율은 $8 \%$ 근방의 큰 값 을 보였다. ${ }^{23}$ 하지만 이 경우에도 부가적인 첨가물로서 $\mathrm{Zn}$-아세테이트나 아세트산을 첨가하는 것이 일반적이어 서 $\mathrm{SnO}_{2}$ 의 표면에 퍼텐셜에너지 장벽이 형성되는 것도 가능하여 광전특성의 향상은 두 요소가 복합적으로 작용 한 결과로 생각된다. 본 연구에는 두 입자를 혼합한 것 이 외에 $\mathrm{Zn}$-아세테이트나 아세트산 등을 첨가하지 않았기 때문에 $\mathrm{SnO}_{2}$ 표면의 개질은 불가능하므로 이에 따른 전 하 재조합의 개선 효과는 배제할 수 있다. 반면에 $\mathrm{SnO}_{2}$ $\mathrm{ZnO}$ 의 복합전극에서의 전하분리의 향상은 가능하지만 본 연구에서는 기존연구에서 $\mathrm{ZnO}$ 의 함량이 $50 \%$ 근방에서 최대의 성능향상을 유도한 것과는 ${ }^{23}$ 달리 단지 $5 \%$ 의 $\mathrm{ZnO}$ 첨가에서 가장 높은 $\mathrm{Voc}$ 및 변환효율이 얻어진 것은 이러 한 전하분리 향상만으로는 설명하기에 미흡한 것으로 생 각된다.

본 연구에서 관측된 광전특성 향상의 일차적 요인은 전 극의 독특한 나노구조로 생각된다. 기존의 복합전극들은 대개 단순한 나노입자의 혼합체이지만 이 연구에서 제조 된 복합전극은 $\mathrm{SnO}_{2}-\mathrm{ZnO}$ 가 서로 뭉쳐서 낱알모양의 2차 구조를 띠고 이들이 서로 연결되면서 전극을 이루고 있 는 형태를 보였다. 특히 $\mathrm{ZnO}$ 의 첨가량이 작은(5-10\%) 경 우에도 이러한 2 차구조가 나타나고 첨가량이 증가해도
그 형태상의 변화는 거의 없다는 점과 최고효율이 $\mathrm{ZnO}$ $5 \%$ 에서 나타나는 것은 매우 흥미롭다. 이 두 가지 사실은 관측된 광전특성 향상의 일차적 요인이 전극의 독특한 나노구조로 생각할 수 있기 때문이다. $\mathrm{ZnO}$ 첨가량이 $50 \%$ 이하 영역에서는 $\mathrm{ZnO}$ 의 역할이 $\mathrm{SnO}_{2}$ 나노입자가 낱알형 태로 뭉쳐 2차구조를 갖도록 하는 것 이외에는 큰 역할이 없는 것으로 생각된다. 즉. $\mathrm{Voc}$ 는 $\mathrm{SnO}_{2}-\mathrm{ZnO}$ 전극이 나노 낱알 구조를 띠자 곧 증가하였고, 계속 그 값이 유지되었 는데, 이는 나노낱알 구조가 recombination을 감소시키는 데 유리한 구조임을 의미한다.

나노낱알 구조는 두 가지 측면에서 recombination을 줄 이는 데 기여할 수 있을 것으로 기대된다. 우선 낱알을 이 루면서 입자간의 연결성이 더욱 강화되는 것을 생각할 수 있는데 이는 전극 내 전자확산을 촉진시킬 수 있다. 더 욱 중요한 것은 낱알입자간의 큰 공극공간이 존재한다는 사실이다. 큰 공극들이 이루는 전해질의 넓은 확산경로는 $\mathrm{I}_{3}{ }^{-}$이온이 신속하게 전극외부로 확산되어 나갈 수 있도록 도와주고 이에 따라 전극-전해질 계면의 $\mathrm{I}_{3}{ }^{-}$이온의 농도 는 기존 전극에 비해 낮아질 것으로 생각된다. 이에 따라 전극의 표면상태에 갇힌 전자들의 재조합은 줄어들고 Voc와 fill-factor가 증가하는 결과가 가능하다. Jsc의 경우 는 단순 $\mathrm{SnO}_{2}$ 전극에 비해 $\mathrm{ZnO} 5 \%$ 를 첨가한 전극은 재조 합의 감소로 약간 증가하고, 이후 $\mathrm{ZnO} 50 \%$ 까지 감소하는 데 이는 이 영역에서 나노낟알 전극에서 $\mathrm{ZnO}$ 의 광전특성 기여분은 그리 크지 않음을 시사하고 있다. $\mathrm{ZnO}$ 입자크 기가 크다는 점과 $\mathrm{ZnO}$ 의 함량이 아직은 독자적인 $\mathrm{ZnO}$ 연 결네트워크를 형성하기에는 부족하다는 점, 그리고 $\mathrm{ZnO}$ 의 $\mathrm{CBE}$ 가 상대적으로 높다는 점 등을 고려하면 $\mathrm{SnO}_{2}$ 의 표면적은 $\mathrm{ZnO}$ 함량에 반비례하고 이에 따라 감소하고 초 기 광전자생성량이 줄어드는 것이 $\mathrm{Jsc}$ 의 감소원인으로 생 각된다. $\mathrm{ZnO}$ 함량이 $70 \%$ 이상이 되면 $\mathrm{ZnO}$ 입자간의 연결 네트워크가 일부 가능해지면서 Jsc와 변환효율이 다시 증 가하는 것으로 해석된다.

Fig. 4는 $\mathrm{SnO}_{2}-\mathrm{ZnO} \mathrm{DSSC}$ 의 IPCE 결과를 보여준다. $\operatorname{IPCE}\left(\lambda_{\max }=520 \mathrm{~nm}\right)$ 의 $\mathrm{ZnO}$ 함량별 변화는 $\mathrm{Jsc}$ 의 거동과 매 우 유사하여, 나노낱알 구조가 형성되면 값이 크게 증가 하지만, 이 후에는 $\mathrm{ZnO}$ 함량에 따라 감소하여 광전자의 형성도 $\mathrm{SnO}_{2}$ 네트워크에서 주로 일어남을 시사하고 있다. Fig. 4(b)는 정규화된 IPCE거동을 보여준다. 장파장 영역 에서의 IPCE 값은 $(\lambda=630 \mathrm{~nm})$ 낱알이 형성될 때 크게 증 가하고, 이 후에는 완만하게 증가한다. 이는 나노낱알구 조가 도입되면 $\mathrm{SnO}_{2}-\mathrm{ZnO}$ 전극에 광산란 효과를 증가시킬 수 있음을 의미한다. $\mathrm{ZnO}$ 함량이 $10 \%$ 이상에서는 입자크 기가 큰 $\mathrm{ZnO}$ 입자의 개수가 증가하여 추가적인 광산란 효과가 나타나지만, 전체적으로는 나노낱알 구조의 효과 

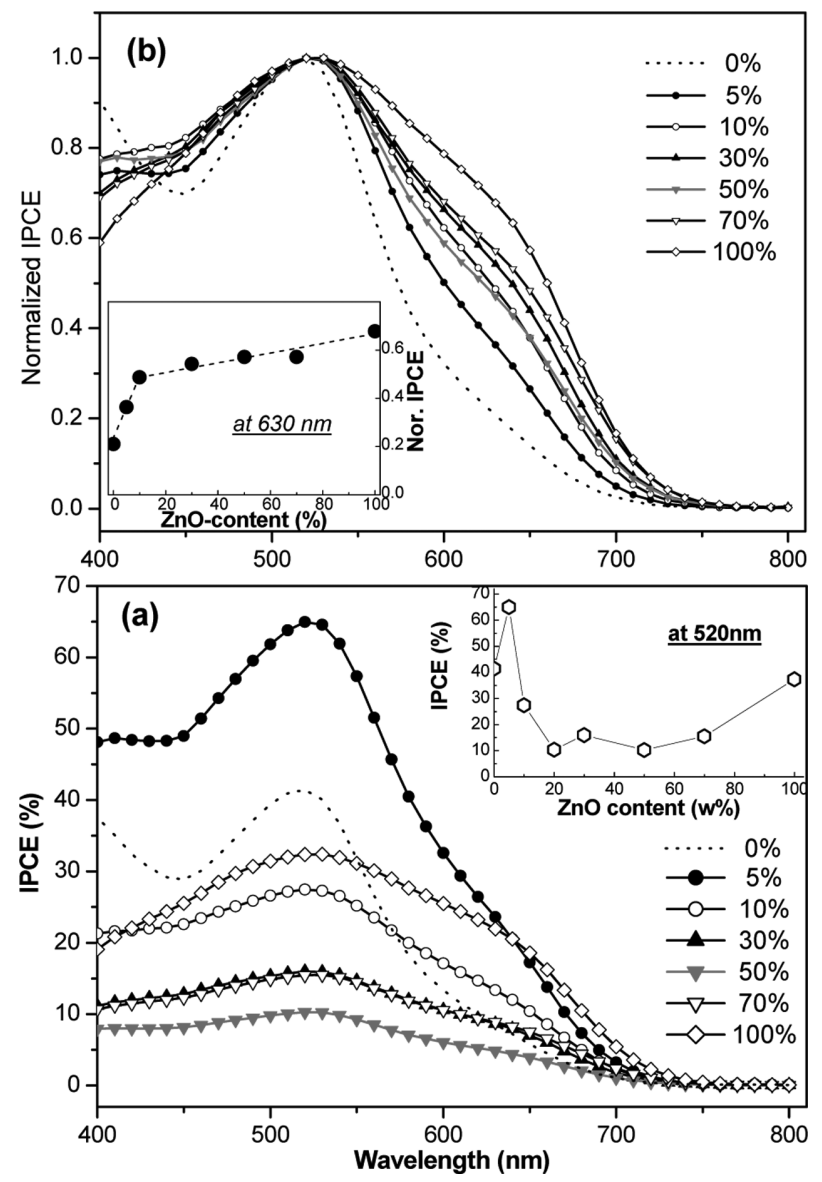

Fig. 4. 나노낱알 $\mathrm{SnO}_{2}$-ZnO-DSSC의 IPCE (a) 및 상대 IPCE 거 동 (b) (inset $630 \mathrm{~nm}$ 에서의 상대 IPCE 값의 변화추이).

\section{가 지배적이라고 할 수 있다.}

본 연구에서는 나노낱알 구조의 $\mathrm{SnO}_{2}-\mathrm{ZnO}$ 복합전극은 $\mathrm{ZnO}$ 가 $\mathrm{SnO}_{2}$ 입자 표면을 coating하는 것이 아니라 $\mathrm{SnO}_{2}$ 입자의 뭉침을 도와주어 $\mathrm{SnO}_{2}$ 입자간 연결성을 증대시키 고, 전극막에 큰 공극을 형성하는 역할을 하는 것을 알 수 있었다. 그 결과 $\mathrm{SnO}_{2}-\mathrm{ZnO}$ 복합전극은 표면상태가 개선 되어 $\mathrm{Voc}$ 가 향상되었고, 장파장 영역에서 광산란 효과를 나타냄을 확인할 수 있었다.

Acknowledgements. 본 연구는 가톨릭대학교 연구기금 (2010)에 의해 지원되었고 이에 감사를 표한다.

\section{REFERENCES}

1. Gratzel, M.; O’Regan, B. Nature 1991, 353, 737.

2. Gratzel, M. J. Photochem. Photobiol. A: Chem. 2004,
$164,3$.

3. Chou, T. P.; Zhang, Q.; Fryxell, G. E.; Cao, G. Adv. Mater. 2007, 19, 2588.

4. Zhang, Y.; Wu, L.; Liu, Y; Xie, E. J. Phys. D: Appl. Phys. 2009, 42, 085105.

5. Kim, K. S.; Kang, Y. S.; Lee, J. H.; Shin, Y. J.; Park, N. G.; Ryu, K. S.; Chang, S. H. Bull. Korean Chem. Soc. 2006, 27, 295.

6. Law, M.; Greene, L.; Johnson, J. C.; Saykally, R.; Yang, P. Nature Materials 2005, 4, 455.

7. Quintana, M.; Edvinsson, T.; Hagfeldt, A.; Boschloo, G. J. Phys. Chem. C 2007, 111, 1035.

8. Lenzmann, F.; Krueger, J.; Burnside, S.; Brooks, K.; Gratzel, M.; Gal, D.; Ruhle, S.; Cahen, D. J. Phys. Chem. B 2001, 105, 6347 .

9. Tennakone, K.; Senadeera, G. K. R.; Perera, V. P. S.; Kottegoda, I. R. M.; De Silva, L. A. A. Chem. Mater. 1999, $11,2474$.

10. Zheng, H.; Tachibana, Y.; Kalantar-zadeh, K. Langmuir 2010, 26, 19148.

11. Huang, M. H.; Mao, S.; Feick, H.; Yan, H.; Wu, Y.; Kind, H.; Weber, E.; Russo, R.; Yang, P. Science 2001, 292, 1897.

12. Keis, K.; Bauer, C.; Boschloo, G.; Hagfeldt, A.; Westermark, K.; Rensmo, H.; Siegbahn, H. J. Photochem. Photobiol. A. 2002, 148, 57.

13. Green, A. N. M.; Palomares, E.; Haque, S. A.; Kroon, J. M.; Durrant, J. R. J. Phys. Chem. B. 2005, 109, 12525.

14. Chappel, S.; Zaban, A. Solar Energy Materials \& Solar Cells 2002, 71, 141.

15. Shin, Y. J. Polymer Science and Technology 2006, 17, 446.

16. Lee, J. H.; Park, N. G.; Shin, Y. J. Solar Energy Materials \& Solar Cells 2011, 95, 179.

17. Senevirathna, M. K. I.; Pitigala, P. K. D. D. P.; Premalal, E. V. A.; Tennakone, K.; Kumara, G. R. A.; Konno, A. Solar Energy Materials \& Solar Cells 2007, 91, 544.

18. Green, A. N.; Palomares, E.; Haque, S. A.; Kroon, J. M.; Durrant, J. R. J. Phys. Chem. B 2005, 109, 12525.

19. Kay, A.; Gratzel, M. Chem. Mater. 2002, 14, 2930.

20. Spanhel, L.; Anderson, M. A.; J. Am. Chem. Soc. 1991, 113, 2826.

21. Meulenkamp, E. A.; J. Phys. Chem. B 1998, 102, 5566.

22. Niinobe, D.; Makari, Y.; Kitamura, T.; Wada, Y.; Yanagida, S. J. Phys. Chem. B 2005, 109, 17892.

23. Tennakone, K.; Kumara, G. R. R. A.; Kottegoda, I. R. M.; Perera, V. P. S. Chem. Commun. 1999, 15. 